\title{
Construction of artificial microRNA expression vectors for inhibition of Minc16281 gene in root-knot nematode Meloidogyne incognita
}

\author{
Phong V. Nguyen*, Loan T. N. Nguyen, Thang B. Tran, \& Linh B. Ton \\ Department of Biotechnology, Nong Lam University, Ho Chi Minh city, Vietnam
}

ARTICLE INFO
Research Paper
Received: January 01, 2019
Revised: February 15, 2019
Accepted: February 22, 2019
Keywords
Effector
Gene silencing
Meloidogyne
MicroRNA
Plant-parasitic nematode
*Corresponding author
Nguyen Vu Phong
Email: nvphong@hcmuaf.edu.vn

Cited as: Nguyen, P. V., Nguyen, L. T. N., Tran, T. B. \& Ton, L. B. (2019). Construction of artificial microRNA expression vectors for inhibition of Minc16281 gene in root-knot nematode Meloidogyne incognita. The Journal of Agriculture and Development 18(4), 62-69.
Effectors have been identified to play a very important role in the parasitism of plant-parasitic nematode. To cope with this type of pathogen, many approaches of silencing genes encoding for effectors have been studied and promise to be an effective tool to create plant varieties resistant to plant-parasitic nematodes. In this study, the Minc16281 gene encoding a pioneer effector with unknown function was determined and cloned from a Meloidogyne incognita population isolated from soybean field (ID: MH315945.1). The nucleotide sequence of this gene showed $97 \%$ identity to its homolog in GenBank (ID: JK287445.1) used as the control strain in our research. To generate host-induced gene silencing constructs which can potentially silence the expression of Minc16281 gene, two artificial microRNAs were synthesized based on the miR319a structure of Arabidopsis thaliana and inserted into an expression vector in soybean. These microRNAs can be introduced into soybean to investigate the function of MINC16281 on parasitism of root-knot nematode. 


\title{
Tổng hợp vector mang cấu trúc microRNA nhân tạo sử dụng ức chế sự biểu hiện gene Minc16281 của tuyến trùng sung rễ Meloidogyne incognita
}

\author{
Nguyễn Vũ Phong*, Nguyễn Thị Ngọc Loan, Trần Bảo Thắng \& Tôn Bảo Linh \\ Bộ Môn Công Nghệ Sinh Học, Trường Đại Học Nông Lâm TP.HCM, TP. Hồ Chí Minh
}

THÔNG TIN BÀI BÁO
Bài báo khoa học
Ngày nhận: 01/01/2019
Ngày chỉnh sửa: 15/02/2019
Ngày chấp nhận: 22/02/2019
Từ khóa
Câm lặng gene
Effector
Meloidogyne
MicroRNA
Tuyến trùng ký sinh thực vật
*Tác giả liên hệ
Nguyễn Vũ Phong
Email: nvphong@hcmuaf.edu.vn

\section{TÓM TẮT}

Các effector được nhận định có vai trò rất quan trọng trong quá trình ký sinh của tuyến trùng sưng rễ gây hại cây trồng. Để kiểm soát sinh vật gây hại này, nhiều phương pháp kìm hãm sự biểu hiện các gene mã hóa effector được tập trung nghiên cứu và có tiềm năng trở thành công cụ hữu hiệu tạo ra giống cây trồng kháng tuyến trùng ký sinh thực vật. Trong nghiên cứu này, gene Minc16281 mã hóa cho một effector chưa hiểu rõ chức năng được phân lập từ loài tuyến trùng Meloidogyne incognita ký sinh cây đậu nành ở Việt Nam (ID: MH315945.1). Trình tự của gene này tương đồng $97 \%$ với trình tự hiện diện trên GenBank (ID: JK287445.1). Từ trình tự cDNA của gene này, hai cấu trúc microRNA nhân tạo có khả năng làm câm lặng gene này được tổng hợp nhờ phân tử tiền thân miR319a của cây Arabidopsis thaliana. Các miRNA nhân tạo được chèn vào vector biểu hiện ở cây đậu nành để nghiên cứu vai trò và chức năng của effector MINC16281 của tuyến trùng sưng rễ.

\section{1. Đặt Vấn Đề}

Tuyến trùng sưng rễ Meloidogyne sp. là loài tuyến trùng ký sinh gây thiệt hại kinh tế lớn nhất trên cây trồng ở vùng ôn đới và nhiệt đới (Trudgill \& Block, 2001). Loài tuyến trùng này có khả năng ký sinh hơn 5.500 loài thực vật, ký chủ ưa thích là rau cải, cây họ đậu, cây lấy sợi, cây ăn quả và cây trồng đồn điền. Đến nay, Meloidogyne được biết có trên 100 loài, trong đó 4 loài $M$. incognita, M. javanica, $M$. arenaria, $M$. hapla là ký sinh gây hại nghiêm trọng (Hunt \& Handoo, 2009). Tuyến trùng sưng rễ có tính ký sinh chuyên tính cao, khả năng tiềm sinh lâu trong đất. Do đó mức độ ảnh hưởng của tuyến trùng rất lớn đến năng suất và chất lượng sản phẩm cũng như trong vấn đề tái sản xuất nông nghiệp.

Trong nghiên cứu này, gene Minc16281 mã hóa cho một effector chưa biết chức năng được tạo dòng từ mẫu tuyến trùng $\mathrm{M}$. incognita tạo dữ liệu cho tổng hợp các microRNA nhân tạo có khả năng bất hoạt gene này. Các cấu trúc RNAi này được gắn vào vector biểu hiện ở cây đậu nành nhằm tìm hiểu vai trò của effector MINC16281 trong tiến trình ký sinh thực vật của tuyến trùng sưng rễ thông qua con đường làm câm lặng gene bởi cây chủ.

\section{Vật Liệu và Phương Pháp Nghiên Cứu}

\subsection{Vật liệu}

Dòng tuyến trùng sưng rễ Meloidogyne incognita phân lập từ rễ cây đậu nành được định danh dựa vào hình thái vân sinh môn con cái (perineal pattern) (Eisenback \& Triantaphyllou, 1991) và chỉ thị SCAR (Meng \& ctv., 2004). Dòng tuyến trùng được lưu giữ và nhân dòng trên cây đậu nành giống Nam Vang.

Vector pRS300 chứa ath-miR319a precursor được cung cấp bởi Detlef Weigel, Department of Molecular Biology, Max Planck Institute for De- 
velopmental Biology, Đức (Schwab \& ctv., 2006). Vector pSM103 chứa các gene hptII (kháng hygromycin), gene aadA (kháng kanamycin), cassette 35SP-erGFP7INT-NOS, đoạn miR319a của Arabidopsis chịu điều khiển bởi promoter GmUbiIII giúp biểu hiện đoạn microRNA ở cây đậu nành được cung cấp bởi Andrew F. Bent, University of Wisconsin-Madison, Mỹ (Melito \& ctv. 2010).

\subsection{Tạo dòng gene Minc16281 của tuyến trùng $M$. incognita}

RNA tổng số của tuyến trùng được tách chiết bởi GeneJET RNA Purification Kit (Thermo Scientific, Mỹ), tiếp đến tổng hợp cDNA bằng RevertAid First Strand cDNA Synthesis Kit (Thermo Scientific, Mỹ). Đoạn trình tự mã hóa protein được khuếch đại bằng $\mathrm{PCR}$ với cặp primer Minc16281F (5'- ATGAATCCACAAAGAATGCTCTTCTCT - 3') và Minc16281R (5'TTAAAGAAATGCTGCCATTGGGCGA - 3'). Nhiệt độ bắt cặp được khảo sát ở $52^{0} \mathrm{C}, 54^{0} \mathrm{C}$, $56^{\circ} \mathrm{C}$ và $58^{0} \mathrm{C}$. Chu kì nhiệt gồm 35 chu kỳ $94^{0} \mathrm{C} / 30$ giây, $\mathrm{Ta} / 30$ giây, $72^{0} \mathrm{C} / 45$ giây (35 chu kỳ). Sản phẩm PCR được tinh sạch bằng GenJET Gel Extraction Kit (Thermo Scientific, Mỹ) và được nối với vector pJET1.2/blunt (CloneJET PCR Cloning Kit, Thermo Scientific). Sản phẩm nối được biến nạp vào tế bào $E$. coli TOP10 bằng phương pháp sốc nhiệt (Sambrook \& Russell, 2001). Các khuẩn lạc chứa vector tái tổ hợp được sàng lọc bằng PCR khuẩn lạc với cặp primer pJET1.2. Plasmid tái tổ hợp được tách chiết bằng GeneJET Plasmid Miniprep Kit (Thermo Scientific, Mỹ) và gene tạo dòng được giải trình tự theo phương pháp Sanger.

\subsection{Lựa chọn và tạo dòng cấu trúc miRNA nhân tạo}

Dựa vào trình tự gene Minc16281 được tạo dòng, các microRNA nhân tạo (amiRNA) có khả năng làm câm lặng biểu hiện gene mục tiêu được thiết kế nhờ công cụ Designer của trang web WMD3 (http://wmd3.weigelworld.org). Từ danh sách các amiRNA nhân tạo gợi ý được đưa ra bởi WMD3, kiểm tra và lựa chọn amiRNA theo tiêu chí được đề xuất bởi Schwab \& ctv. (2006) gồm (1) bất hoạt gene mục tiêu ở tuyến trùng mà không bất hoạt các gene của đậu nành nhờ công cụ Target Search của WMD3 trên hai database Glycine max v1.0 (JGI) và
Glycine max v109 (Phytozome); (2) vị trí gắn của miRNA nhân tạo với mRNA mục tiêu nằm ở vùng 3'; (3) năng lượng liên kết giữa amiRNA với mRNA mục tiêu từ -35 đến $-40 \mathrm{kcal} / \mathrm{mol}$, không cao quá $-30 \mathrm{kcal} / \mathrm{mol}$; (4) không bắt cặp sai từ vị trí 2 - 12 của amiRNA đối với đoạn mục tiêu. Công cụ Oligo của WMD3 được sử dụng thiết kế các primer để thay thế đoạn $20 \mathrm{nu}$ của precursor ath-mi319a bởi đoạn miRNA $21 \mathrm{nu}$ mới nhờ kỹ thuật PCR overlapping theo Schwab \& ctv. (2006) (http://wmd3.weigelworld.org) (Bảng 1). Cấu trúc amiRNA mới được chèn trình tự nhận biết của hai enzyme $P s t \mathrm{I}$ và $B a m \mathrm{HI}$ ở hai đầu với primer At319a-F (5'cccCTGCAGccccaaacacacgc-3') và At319a-R (5'cccGGATCCccccatggcgatg-3') và nhân dòng bởi hệ thống vector pJET1.2/blunt (Thermo Scientific, Mỹ). Trình tự microRNA nhân tạo được kiểm tra nhằm đảm bảo tính chính xác trước khi gắn vào vector biểu hiện pSM103.

\subsection{Chèn cấu trúc miRNA nhân tạo vào vec- tor biểu hiện}

Đoạn miR319a trong plasmid pSM103 được thay thế bằng đoạn trình tự amiRNA tổng hợp. Plasmid pSM103 và đoạn amiRNA được xử lý bằng enzyme cắt BamHI và PstI (Thermo Scientific, Mỹ) và nối với nhau nhờ $\mathrm{T} 4 \mathrm{DNA}$ ligase (Thermo Scientific, Mỹ) để tạo plasmid tái tổ hợp. Plasmid tái tổ hợp pSM103-amiRNA được tạo dòng trong tế bào E. coli TOP10 khả biến bằng phương pháp sốc nhiệt. Trình tự và hướng chèn của amiRNA trong vector pSM103 được kiểm tra trước khi biến nạp plasmid tái tổ hợp vào vi khuẩn Agrobacterium tumefaciens LBA4404 để chuyển cấu trúc amiRNA vào cây chủ.

\subsection{Kiểm tra trình tự các đoạn polynucleotide}

Phân tích trình tự nucleotide bằng phần mềm BioEdit, công cụ BLAST (NCBI), Clustal Omega được phát triển bởi EMBL - EBI (http://www.ebi.ac.uk/Tools/msa/clustalo/) và so dòng bằng ESPript 3.0 (http://espript.ibcp.fr/ ESPript/cgi-bin/ESPript.cgi).

\section{Kết Quả và Thảo Luận}

\subsection{Tạo dòng gene Minc16281}

Từ cDNA tổng số của dòng tuyến trùng phân lập đã khuếch đại được sản phẩm có kích thước 


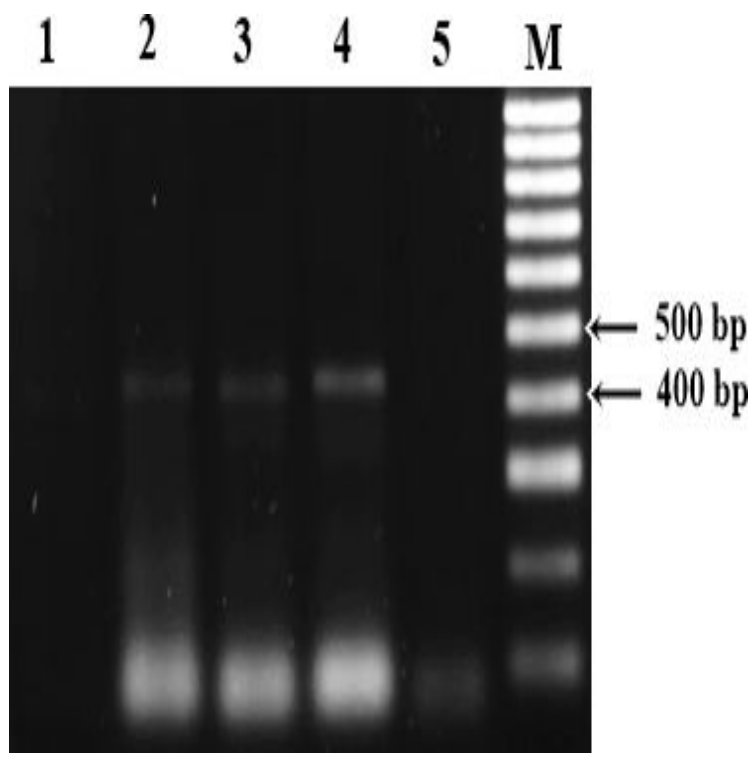

Hình 1. Kết quả PCR khuếch đại gene Minc16281 với nhiệt độ bắt cặp khác nhau.

(M) ladder $100 \mathrm{bp} ;(1-4): 52^{0} \mathrm{C}, 54^{0} \mathrm{C}, 56^{\circ} \mathrm{C}, 58^{0} \mathrm{C}$; (5) đối chứng âm.

khoảng 400 bp tương ứng với kích thước gene mục tiêu (Hình 1).

Trình tự đoạn cDNA khuếch đại từ dòng tuyến trùng thu thập được tạo dòng trong vi khuẩn $E$. coli TOP10 sử dụng vector pJET1.2/blunt (Hình 2). Trình tự đoạn cDNA mục tiêu được giải trình tự và so sánh với dư liệu bộ gene của tuyến trùng sưng rễ Meloidogyne (Abad \& ctv., 2008; https://www6.inra.fr/meloidogyne_incognita) và NCBI. Kết quả cho thấy có sự tương đồng đến $97 \%$ với cDNA của 3 loài tuyến trùng $M$. incognita, M. javanica, $M$. arenaria. Trình tự cDNA của gene Minc16281 đã được đăng ký vào GenBank (ID: MH315945.1) và sử dụng làm khuôn để thiết kế các miRNA nhân tạo.

\subsection{Chọn lọc và tổng hợp miRNA nhân tạo}

Trình tự đoạn gene Minc16281 của dòng tuyến trùng Meloidogyne incognita Mi-PN03 (ID: MH315945.1) được sử dụng để chọn lựa các miRNA nhân tạo nhờ phần mềm WMD3. Từ danh sách các amiRNA gợi ý tiến hành kiểm tra và chọn hai amiR ứng viên ký hiệu là amiR16281.1 và amiR16281.2 (Bảng 2).

Các đoạn amiRNA được tổng hợp bằng phương pháp PCR overlapping theo quy trình miêu tả bởi Schwab \& ctv. (2006). Do quy trình thực hiện tổng hợp hai microRNA là tương tự nhau nên kết

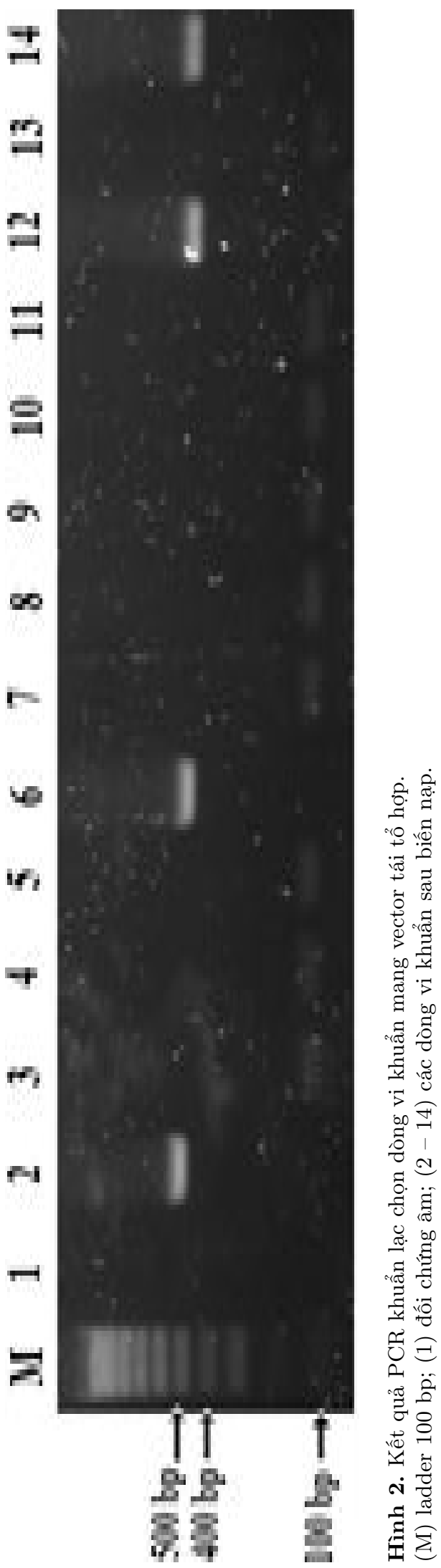

Tạp chí Nông nghiệp và Phát triển 18(4) 
Bảng 1. Các primer sử dụng tổng hợp amiR16281

\begin{tabular}{lll}
\hline amiRNA & Primer & Trình tự (5’3') \\
\hline & I miR & gaTACTAACAGGCAAATACGCACtctctcttttgtattcc \\
amiR16281.1 & II miR & gaGTGCGTATTTGCCTGTTAGTAtcaaagagaatcaatga \\
& III miR*s & gaGTACGTATTTGCCAGTTAGTTtcacaggtcgtgatatg \\
& IV miR*a & gaAACTAACTGGCAAATACGTACtctacatatatattcct \\
\hline & I miR & gaTAAATACACACTACGCGTCCAtctctcttttgtattcc \\
amiR16281.2 & II miR & gaTGGACGCGTAGTGTGTATTTAtcaaagagaatcaatga \\
& III miR*s & gaTGAACGCGTAGTGAGTATTTTtcacaggtcgtgatatg \\
& IV miR*a & gaAAAATACTCACTACGCGTTCAtctacatatatattcct \\
\hline
\end{tabular}

Bảng 2. Trình tự hai microRNA nhân tạo lựa chọn

\begin{tabular}{clccc}
\hline Tên & Trình tự & $\begin{array}{c}\text { Năng lượng } \\
\text { liên kết } \\
(\mathrm{kcal} / \mathrm{mol})\end{array}$ & $\% \mathrm{GC}$ & $\begin{array}{c}\text { Vị trí bắt cặp } \\
\text { với mRNA } \\
\text { mục tiêu }\end{array}$ \\
\hline amiR16281.1 & UACUAACAGGCAAAUACGCAC & $-38,92$ & 42 & $65-74$ \\
amiR16281.2 & UAAAUACACACUACGCGUCCA & $-40,20$ & 42 & $51-70$ \\
\hline
\end{tabular}

quả tổng hợp amiR16281.2 được trình bày trong phần này.

Sau khi xác định nhiệt độ bắt cặp tối ưu cho các primer và thời gian kéo dài thích hợp của từng phản ứng thành phần $(\mathrm{a}, \mathrm{b}, \mathrm{c})$ đã thu được được sản phẩm có kích thước lần lượt khoảng 119 bp, 176 bp, 182 bp. Các sản phẩm này dùng làm khuôn cho PCR overlapping (d) tổng hợp đoạn precursor mang đoạn amiRNA kích thước lớn hơn 400 bp tương đương kích thước lý thuyết mong đợi (Hình 3).

Cấu trúc precursor ath-mi319a mang amiR16281.2 được tạo dòng nhờ vector pJET1.2/blunt. Sản phẩm nối được biến nạp vào $E$. coli TOP10 để chọn dòng mang vector tái tổ hợp bằng kỹ thuật $\mathrm{PCR}$ khuẩn lạc. Kết quả điện di sản phẩm PCR từ 12 khuẩn lạc cho thấy có 10 dòng tạo sản phẩm tương đương kích thước dự kiến 546 bp (Hình 4).

Plasmid tái tổ hợp của ba dòng vi khuẩn được tách chiết và giải trình tự. Kết quả cho thấy cấu trúc amiR16281.2 tạo dòng có chiều dài và trình tự đúng với dự tính (Hình 5). Cấu trúc này được thu nhận và nối với backbone của vector biểu hiện pSM103.

\subsection{Tạo vector biểu hiện cấu trúc amiRNA}

Vector pSM103 và vector pJET1.2amiRNA16281.2 được xử lý bằng enzyme cắt BamHI và PstI (Thermo Scientific, Mỹ). Theo lý thuyết phản ứng cắt vector pSM103 tạo ra hai đoạn có kích thước $412 \mathrm{bp}$ và $12 \mathrm{~kb}$,

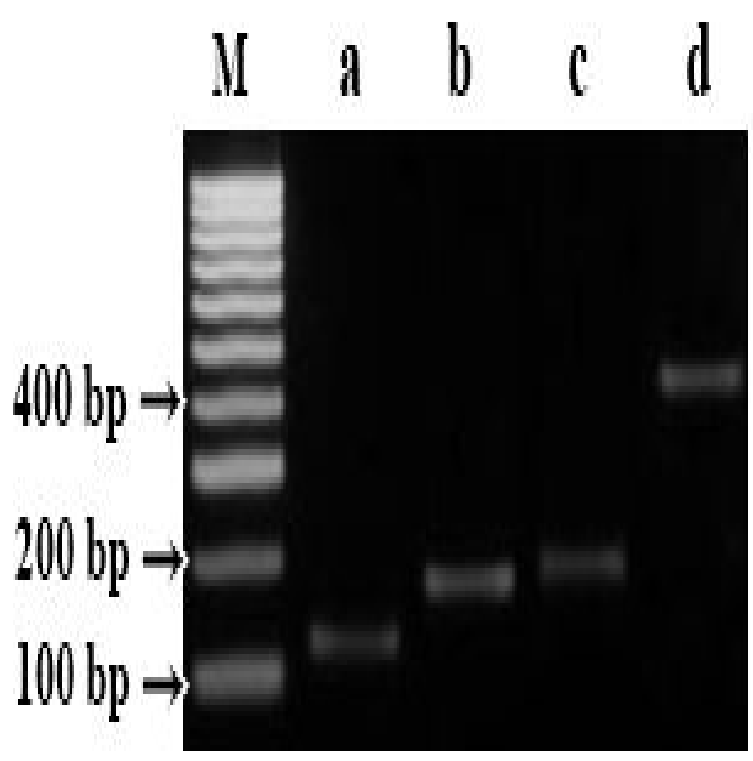

Hình 3. Kết quả PCR tổng hợp đoạn amiR16281.2. (M) ladder 100 bp; (a, b, c, d) các phản ứng thành phần.

vector pJET1.2-amiRNA16281.2 khi bị cắt bằng sẽ tạo ra hai đoạn có kích thước 428 bp và 2974 bp. Thực tế, kết quả điện di sản phẩm cắt vector pSM103 thu được một băng có kích thước lớn hơn $10 \mathrm{~kb}$ và một băng lớn hơn 400 bp (Hình 6a), vector pJET1.2-amiRNA16281.2 cho một băng có kích thước gần $3 \mathrm{~kb}$ và một băng lớn hơn 400 bp (Hình 6b).

Sản phẩm mục tiêu được thu hồi từ gel agarose và nối với nhau bằng enzyme $\mathrm{T} 4$ ligase tạo vec- 


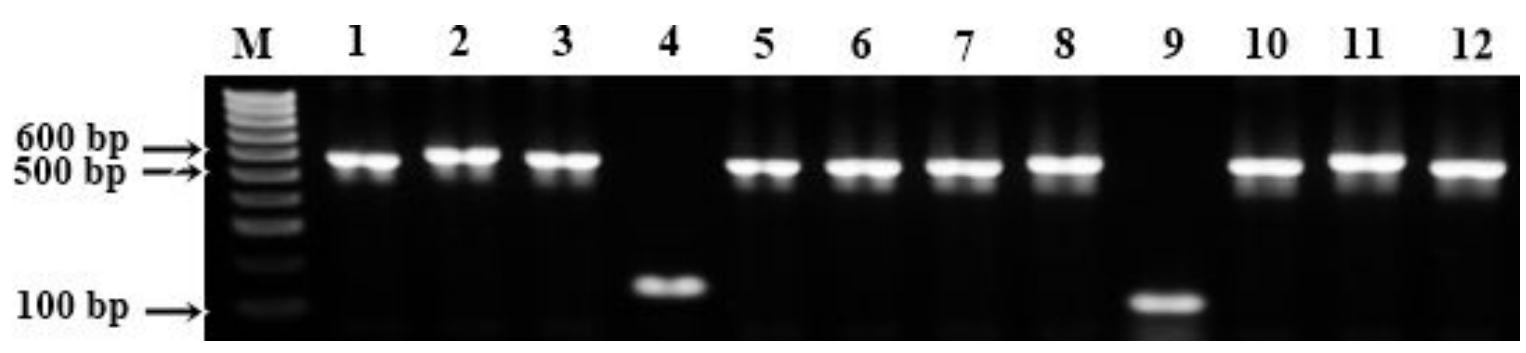

Hình 4. Kết quả PCR kiểm tra dòng vi khuẩn mang vector tái tổ hợp. (M) ladder 100bp, (1-12) các khuẩn lạc.

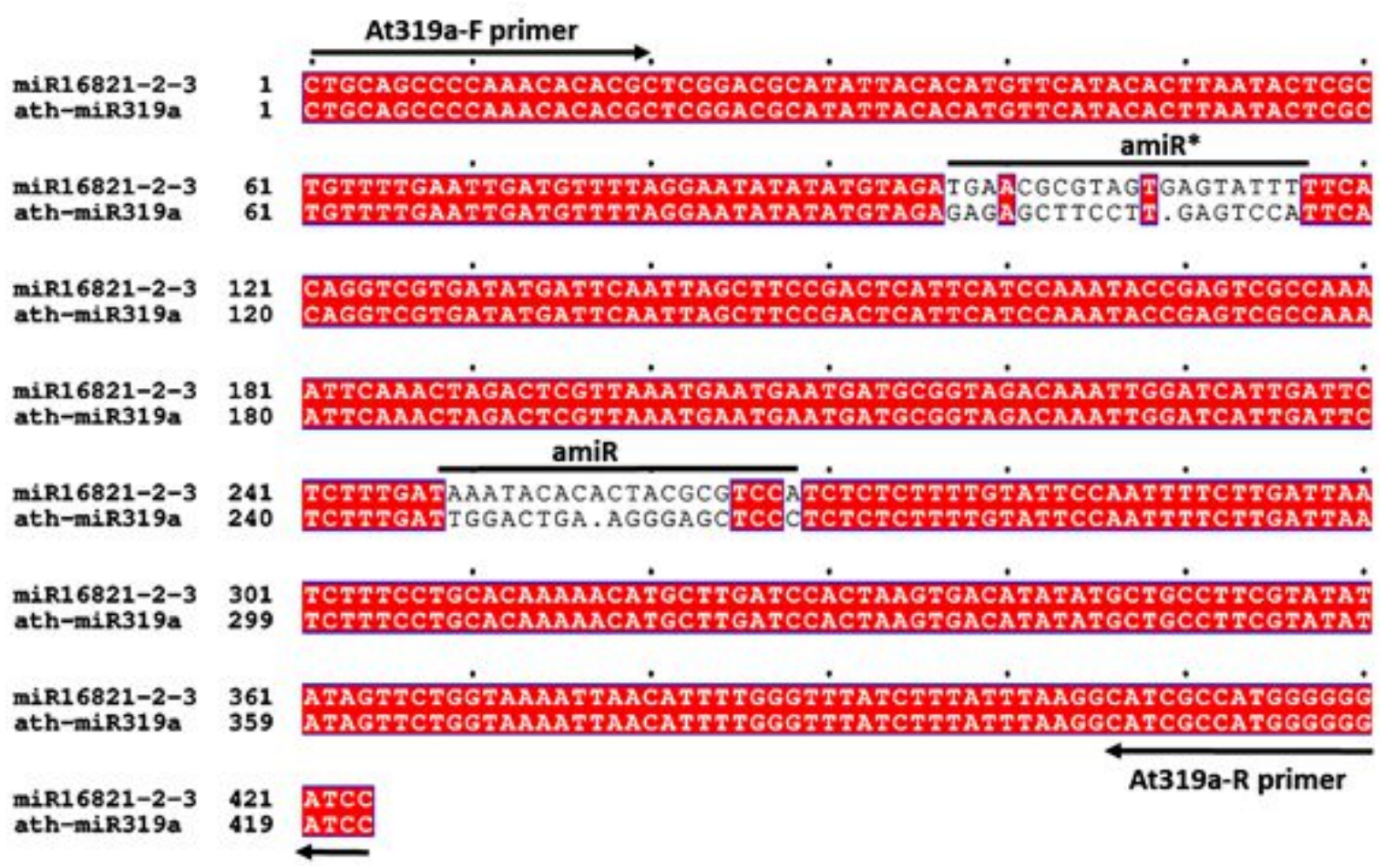

Hình 5. Trình tự 21 nu amiR16281-2 thay thế vào trình tự 20 nu của precursor ath-mR319a.

tor tái tổ hợp pSM103-amiR16281.2. Vector tái tổ hợp được biến nạp vào tế bào khả nạp $E$. coli TOP10 bằng phương pháp sốc nhiệt. Các dòng vi khuẩn chứa vector tái tổ hợp được sàng lọc bằng $\mathrm{PCR}$ khuẩn lạc (Hình 7). Kết quả kiểm tra bằng enzyme cắt và giải trình tự cho thấy amiR16281.2 được chèn thành công vào vector biểu hiện pSM103 (Hình 8).

Kết quả cho thấy đã tạo dòng thành công hai vector chứa cấu trúc amiRNA16281 nhân tạo trong vi khuẩn $E$. coli. Các cấu trúc này được thu nhận và tiếp tục biến nạp vào vi khuẩn A. tumefaciens LBA4404 bằng phương pháp sốc nhiệt. Dòng vi khuẩn chứa vector tái tổ hợp đã được chọn lọc trên môi trường chứa kháng sinh kanamycin và sẽ được chuyển vào cây đậu nành trong nghiên cứu tiếp theo.

Minc16281 là gene mã hóa một effector chưa biết chức năng của tuyến trùng $M$. incognita. Effector này chứa một đoạn peptide tín hiệu (signal peptide) ở đầu $\mathrm{N}$-terminal và trình tự xuyên màng (transmembrane domain). Kết quả thực nghiệm cho thấy khi xử lý tuyến trùng vởi siRNA chuyên biệt cho mRNA bằng phương pháp soaking đã làm giảm hơn $50 \%$ độc tính của tuyến trùng (dữ liệu chưa công bố). Trong nghiên cứu 
(a)

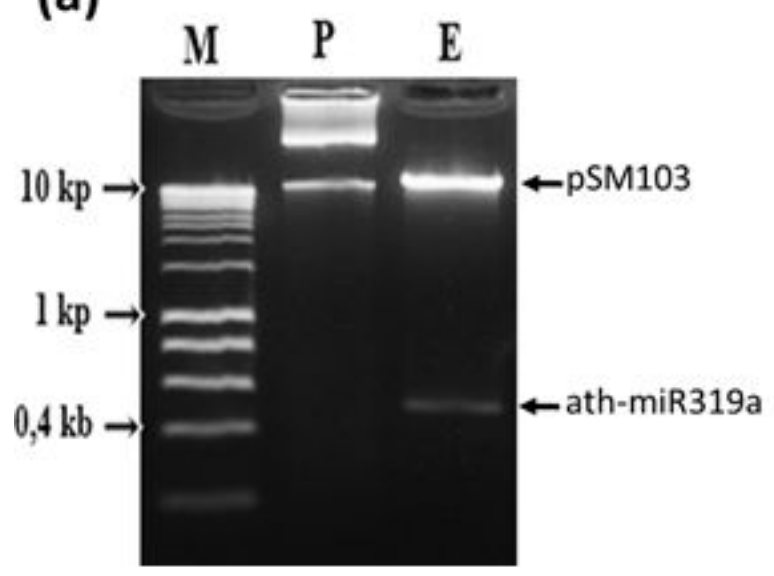

(b)

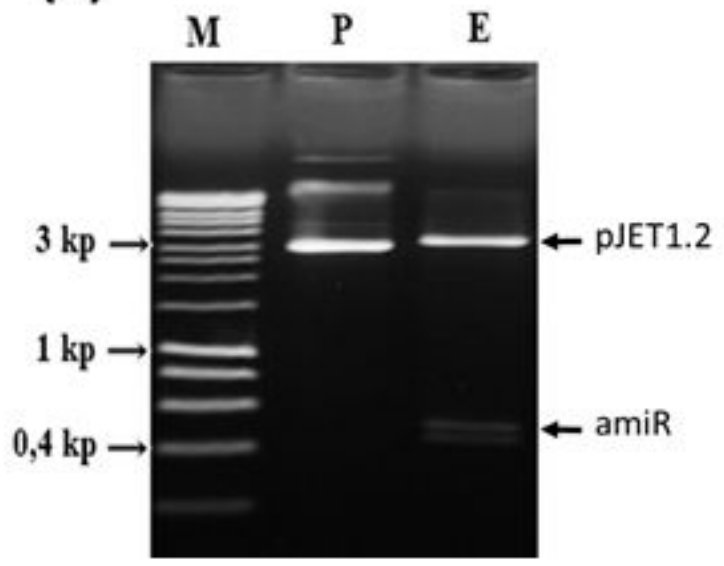

Hình 6. Kết quả cắt vector (a) pSM103 và (b) pJET1.2-amiR16281.2.

$(\mathrm{M})$ : Ladder $1 \mathrm{~kb} ;(\mathrm{P})$ : plasmid; $(\mathrm{E})$ : cắt bằng $B a m \mathrm{HI}$ và $P s t \mathrm{I}$.

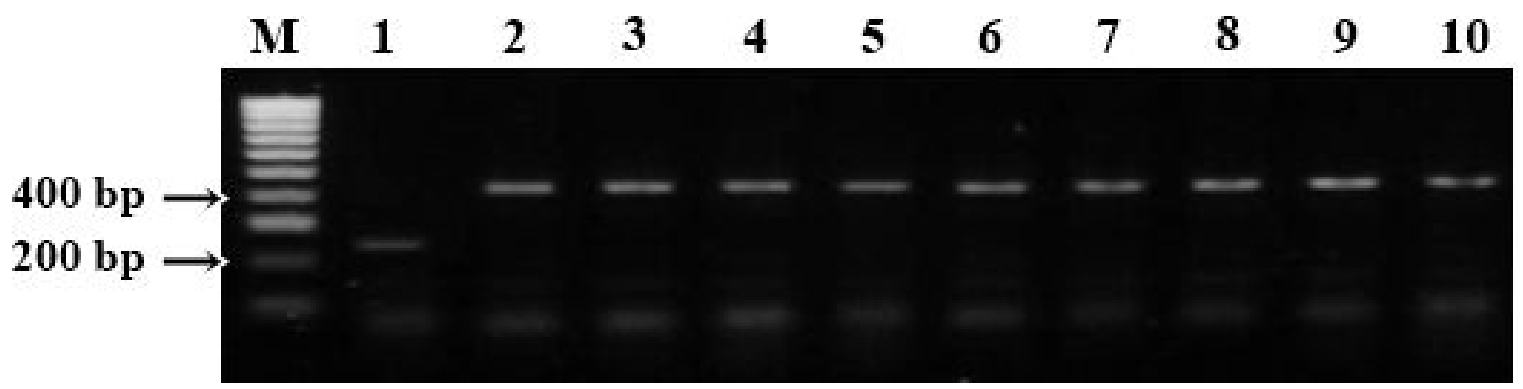

Hình 7. Kết quả PCR sàng lọc dòng vi khuẩn mang vector tái tổ hợp.

(M) ladder 100bp; (1) đối chứng 261 bp; $(2-10)$ các khuẩn lạc.

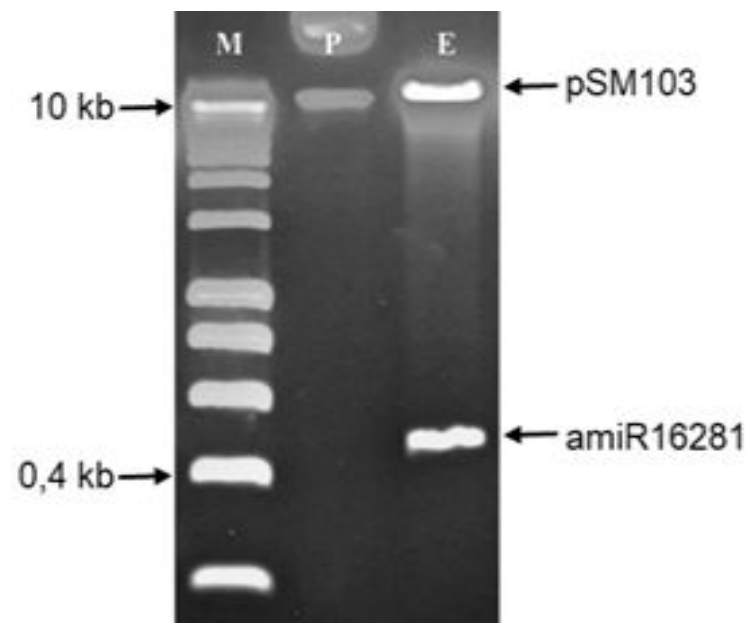

Hình 8. Kết quả cắt vector pSM103-amiR16281.2. $(\mathrm{M})$ : Ladder $1 \mathrm{~kb} ;(\mathrm{P})$ : không cắt; $(\mathrm{E})$ : Bam HI và $P$ st I. này, trình tự gene Minc16281 của tuyến trùng Meloidogyne incognita PN03 ký sinh đậu nành phân lập ở Việt Nam đã được xác định tương đồng $97 \%$ với trình tự homolog của $\mathrm{M}$. incognita race 1, EST (expressed sequence tag) của $M . j a-$ vanica và $M$. arenaria. Điều này rất thú vị, có thể giúp ức chế sự biểu hiện của gene mã hóa effector của nhiều loài Meloidogyne bởi một cấu trúc microRNA nhân tạo. Để tìm hiểu chức năng liên quan đến độc tính của effector này ở tuyến trùng, hai cấu trúc miRNA nhân tạo đã được tổng hợp nhằm kiểm tra mức độ biểu hiện của effector tuyến trùng thông qua cây ký chủ (HIGS). Công việc tạo cây đậu nành biến đổi gene và thử nghiệm sinh học cần tiếp tục thực hiện để làm sáng tỏ vai trò của effector, cung cấp thêm dữ liệu cho lựa chọn phương thức kiểm soát tuyến trùng sưng rễ ở cây trồng. 


\section{Kết Luận}

Trình tự mã hóa gene Minc16281 đã được tạo dòng từ dòng tuyến trùng $M$. incognita Mi-PN03. Dựa vào trình tự mã hóa amino acid của đoạn gene này đã thiết kế và tổng hợp hai vector chứa cấu trúc miRNA nhân tạo có khả năng bất hoạt sự biểu hiện của gene Minc16281. Hai vector này đã được biến nạp vào vi khuẩn $A$. tumefaciens LBA4404 phục vụ tạo cây đậu nành biến đổi gene nhằm làm sáng tỏ vai trò của effector tương ứng liên quan đến khả năng ký sinh của tuyến trùng Meloidogyne incognita thông qua phương pháp câm lặng gene cảm ứng bởi cây ký chủ (HIGS).

\section{Lời Cảm Ơn}

Cảm ơn Lê Thị Phương Duy và Huỳnh Thị Mỹ Liên đã hỗ trợ công việc kỹ thuật. Nghiên cứu thuộc đề tài mã số 58/2017/HĐ-SKHCN được tài trợ kinh phí bởi Sở Khoa học và Công nghệ Thành phố Hồ Chí Minh.

\section{Tài Liệu Tham Khảo (References)}

Abad, P., Gouzy, J., Aury, J. M., Castagnone-Sereno, P., Danchin, E. G., Deleury, E., Perfus-Barbeoch, L., Anthouard, V., Artiguenave, F., Blok, V. C., Caillaud, M. C., Coutinho, P. M., Dasilva, C., De Luca, F., Deau, F., Esquibet, M., Flutre, T., Goldstone, J. V., Hamamouch, N., Hewezi, T., Jaillon, O., Jubin, C., Leonetti, P., Magliano, M., Maier, T.R., Markov, G. V., McVeigh, P., Pesole, G., Poulain, J., RobinsonRechavi, M., Sallet, E., Ségurens, B., Steinbach, D., Tytgat, T., Ugarte, E., van Ghelder, C., Veronico, P., Baum, T. J., Blaxter, M., Bleve-Zacheo, T., Davis, E. L., Ewbank, J. J., Favery, B., Grenier, E., Henrissat, B., Jones, J. T., Laudet, V., Maule, A. G., Quesneville, H., Rosso, M. N., Schiex, T., Smant, G., Weissenbach, J., Wincker, P. (2008). Genome sequence of the Metazoan Plant-Parasitic Nematode Meloidogyne incognita. Nature Biotechnology 26(8), 909-915.
Bellafiore, S., Shen, Z., Rosso, M. N., Abad, P., Shih, P., \& Briggs, S. P. (2008). Direct identification of the Meloidogyne incognita secretome reveals proteins with host cell reprogramming potential. PLoS Pathogens 4(10), e1000192.

Davis, E., Hussey, R. S., \& Baum, T. J. (2004). Getting to the roots of parasitism by nematodes. Trends in Parasitology 20(3), 134-141.

Eisenback, D. E., \& Triantaphyllou, H. H. (1991). Rootknot nematodes: Meloidogyne species and races. In Nickle, W. R. (Ed.). Manual of Agricultural Nematology (191-274). New York, America: Marcel Dekker Inc.

Hunt, D. J., \& Handoo, Z. A. (2009). Taxonomy, identification and principal species. In Perry, R. N., Moens, M., \& Starr, J. L. (Eds.). Root-knot nematodes (55-88). Oxfordshire, England: CABI Publishing.

Melito, S., Heuberger, A. L., Cook, D., Diers, B. W., MacGuidwin, A. E., \& Bent, A. F. (2010). A nematode demographictv assay in transgenic roots reveals no significant impacts of the Rhg1 locus LRR-Kinase on soybean cyst nematode resistance. BMC Plant Biology 10(1), 104-117.

Meng, Q. P., Long, H., \& Xu, J. H. (2004). PCR assays for rapid and sensitive identification of three major root-knot nematodes, Meloidogyne incognita, M. javanica and M. arenaria. Acta Phytopathologica Sinica 34, 204-210.

Sambrook, J., \& Russell, D. W. (2001). Molecular Cloning: a Laboratory Manual - Volume 1. New York, America: Cold Spring Harbor Laboratory Press.

Schwab, R., Ossowski, S., Riester, M., Warthmann, N., \& Weigel, D. (2006). Highly specific gene silencing by artificial microRNAs in Arabidopsis. Plant Cell 18, 11211133 .

Trudgill, D. L., \& Blok, V. C. (2001). Apomictic, polyphagous root-knot nematodes: Exceptionally successful and damaging biotrophic root pathogens. Annual Review of Phytopathology 39, 53-77. 